\title{
GLOBALNA I LOKALNA PLAŽA NA PRIMJERU DUBROVAČKIH GRADSKIH PLAŽA I PLAŽNIH KULTURA
}

\author{
ANA PERINIĆ LEWIS \\ Institut za antropologiju \\ 10000 Zagreb, Gajeva 32/2 \\ MAJA ADŽIJA \\ 10000 Zagreb, Kuzminečka 55
}

\author{
DOI: $10.17234 /$ SEC.27.11 \\ Prethodno priopćenje / \\ Preliminary communication \\ Primljeno / Received: 1. 3. 2015. \\ Prihvaćeno / Accepted: 2. 6. 2015.
}

Plaža se obično određuje kao "liminalni prostor/zona”, “anomalijska kategorija” između kopna i mora, prirode i kulture. Na njoj se može pratiti dinamika i odnosi između ekonomije, okoliša, politika i društva. Uovom radu analiziraju se globalne i lokalne, mjesne plaže te njihove različite reprezentacije $i$ suodnos $u$ turističkoj ponudi, promociji i brendiranju destinacije. Globalne plaže u brendiranju destinacije predstavljene su standardiziranim opisom mjesta, krajolika, objekata i aktivnosti za provođenje odmora i dokolice, posve nezavisna od priobalnih naselja, stanovnika i njihovih života i kultura. Ona je u suprotnosti s predodžbom plaže kao "kulturne arene" (Löfgren 2002) i "kaleidoskopa kulture" (Lenček i Bosker 1998). Lokalna, mjesna plaža važan je geografski simbol stvarnog krajolika koji lokalne zajednice prepoznaju kao područje dnevnih i sezonskih aktivnosti, kultura, životnih stilova, povijesti $i$ specifičnih tradicija. U turističkim mjestima dolazi do suprotstavljanja i supostojanja ovih dviju predodžbi reprezentacija plaža. Dubrovačke gradske plaže analizirali smo kao resurse, prostore fantazija, želja i očekivanja te kao mjesta pripadanja, života, vizija, potreba i tradicija lokalnih zajednica, kao što je primjerice Divlja liga, amatersko vaterpolsko natjecanje dubrovačkih plaža i uvala.

Ključne riječi: globalna plaža, lokalna plaža, reprezentacije, plažne kulture, Dubrovnik, Divlja liga

\section{ODREĐENJE PLAŽE}

Plaža, žal/žalo, igalo, pržina, lido, sprud, laguna u rječnicima općeg leksika određuje se kao dio obale, graničnog pojasa kopna i vodenih površina, pogodan za kupanje, sunčanje i odmaranje. U geografskim određenjima plaža je dio obale na kojem čovjek ostvaruje kontakt s vodom i morem. Obala zapravo postaje plažom kada je uravnjena, niska, pogodna, oblikovana ili prilagođena ljudskim potrebama da sa solidnog, čvrstog, poznatoga kopnenog prostora ulaze u fluidni i nesigurni prostor vode i mora. Iako može biti i jezerska i riječna, plaža je prije svega sinonim za morsko kupalište. ${ }^{1}$

${ }^{1}$ Plaža (fr. plage), niska uravnjena obala od pijeska ili oblutaka, pogodna za kupanje (u moru, rijeci, jezeru); sinonim i za morsko kupalište (Pomorska enciklopedija 1983:107). 
Ona nije nepromjenjivi fizički krajolik nego prostor nepredvidljivih i konstantnih transformacija: razaranja i obnavljanja. Njezin oblik, izgled ovisi o morskim mijenama, eroziji, nanošenju ili odnošenju materijala, ali i ljudskim intervencijama kojima se kroz povijest preoblikovala i prilagođavala. Iako je prirodni krajolik, od prvih početaka ljudske povijesti čovjek je plažu nastojao kontrolirati i njome upravljati.

U kulturološkim istraživanjima plaža se određuje kao "granica", "linija", "prag" (Bernandes 2010:129), "liminalna zona/liminalni prostor" (Schields 1991:81, 256; Preston-Whyte 2008:349), "anomalijska kategorija" između kopna i mora, prirode i kulture, "koja nije ni jedno ni drugo, ali posjeduje karakteristike obojeg" (Fiske 1983:2). Ona je kao materijalni prostor "zona nesigurnosti”, a kao kulturološki prostor "pogranično područje koje dopušta različitost i hibridnost" (Preston-Whyte 2008:349).

\section{POVIJEST PLAŽE}

Kroz povijest su se percepcije morske obale, plaže i njezina okoliša mijenjale. "Koncept plaže obuhvaća mnoga područja i povijesti" (Löfgren 2002:215). Plaža kakvu danas poznajemo, povijesno govoreći, novija je pojava (Lenček i Bosker 1999:xx). Povjesničar ideja Alain Corbin (1999) temeljito je mapirao konceptualne geografije mora, obala i plaža. Prema njemu, do sredine 18. stoljeća Europljani doživljavaju samo strah i užas pri pomisli na more, a i plaža je dotada imala isključivo utilitarnu funkciju, bila je mjesto koje su koristili ribari, pomorci, trgovci i krijumčari. Koncept plaže mijenjao se od srednjovjekovne vizije mjesta užasa i čistilišne patnje, preko obnavljajućeg očišćenja u 17. stoljeću do primamljivog spoja slikovitog i uzvišene strepnje u romantizmu, mjesta grešno-seksualnog klinča u viktorijanskoj svijesti, krajolika smrti, patnje i povređivanja u ratnim zbivanjima, do erotski nabijene, seksualizirane javne pozornice za tijelo na suvremenim plažama. "Izum plaže" (Corbin 1999:254) pojavljuje se tek od polovine 19. stoljeća i nije došao od onih koji su živjeli uz more nego od onih koji su ga posjećivali. Stanovništvu koje živi uz more i od mora kupanje i plivanje dio su svakodnevice i praktična vještina, nešto što se uči od ranog djetinjstva. Potreba za uređenim i kultiviranim mjestima za ulazak $\mathrm{u}$ more te građenim kupalištima nastaje onda kada na kupanje u priobalne i otočne krajeve dolaze stanovnici kontinentalnih područja koji često nisu 
najvještiji plivači, a oni donose i svoj društveni kodeks ponašanja te moralne norme koje nalažu razdvajanje prostora za kupanje (Kos i Lozzi Baraković 2009:39). Ovakva unifikacija navika i plivačkih vještina "lokalaca" i kontinentalnih došljaka nije potpuno točna. U prošlosti, stanovništvo koje je živjelo uz more i bavilo se ribarskim zanimanjima bilo je manje cijenjeno od težačkog stanovništva. U starijim generacijama, primjerice na našim otocima, nerijetko se susreću ljudi koji nisu naučili plivati i koji nikada nisu osjetili potrebu za kupanjem u moru. Francuski sociolog Jean-Didier Urbain u djelu Na plaži (Sur la plage) (2002:20) navodi da je ljetovanje i boravak uz obalu prije svega društveni fenomen te da plaža za posjetitelje može predstavljati isti prostor, ali posve različiti svijet. Pojava i razvoj turizma bili su presudni za europsko otkriće morske obale i plaže. Utjecaj Grand Toura kao prakse edukativnog, kulturno-povijesnog putovanja bogatih europskih plemića od 16. do 18. stoljeća revolucionarno će utjecati na povijest ukusa i dokolice na plaži. Njihove potrebe i navike uspostavile su institucije i prakse prema kojima će se razvijati europska putovanja na morsku obalu (Lenček i Bosker 1998:53-54). Kupanje u moru i prakse povezane s razvojem kupališnog turizma zahtijevale su nove prilagodbe, ulazak u more ipak je mnogo zahtjevniji od kontemplacije u priobalnom krajoliku. U antici, srednjem vijeku te do 18. stoljeća kupanje je podrazumijevalo održavanje tjelesne higijene u zatvorenim, ograđenim kupalištima, a tek u 19. stoljeću dolazi do otkrića zajedničkog kupanja u moru (Kos i Lozzi Baraković 2009:15-16). Prvo zabilježeno, popularno kupanje u moru pripisuje se princu od Wellsa, poslije kralju Georgeu IV., 1750. godine u Brightonu koji će nakon toga postati kraljevska ljetna rezidencija i potaknuti razvoj odmora uz more (Hannavy 2003:2). Hidroterapija na morskim obalama uključivala je cikluse uranjanja u hladnu morsku vodu, a od sredine 18. stoljeća terapeutski praznici uključivali su, kao dio dnevnih aktivnosti uz more, i strogo nadzirano plivanje uz pomoć posebno osmišljenih sprava i naprava.

Zajedničko kupanje u moru prije svega je imalo medicinsku svrhu. Razvilo se unutar klimatologije, balneologije ${ }^{2}$ i talasoterapije ${ }^{3}$, a ta njegova

2 Balneologija (lat. balneum: kupelj + -logija), znanost koja proučava metode liječenja pomoću prirodnih mineralnih voda i muljeva (peloida).

3 Talasoterapija (od grčke riječi thalassa $=$ more) je liječenje morskom vodom, klimom i morskim elementima. 
primarna zdravstvena svrha nije ga napustila ni danas o čemu svjedoči obilje usluga i životnih stilova povezanih s wellnessom i zdravstvenim turizmom. Sredinom 19. stoljeća medikalizirana plaža (medicalised beach), namijenjena aristokratskoj i buržoaskoj eliti, razvojem industrijalizacije i boljim prometnim povezivanjem zamijenjena je plažom užitka i razonode (pleasure beach) (Shields 1991:81). Od mjesta hidroterapije, pretvara se u mjesto dokolice, rekreacije i relaksacije, da bi na kraju postala mjesto za odmor, različito i razgraničeno od posla, doma i svakodnevice (Fiske 1983:1). Na primjeru detaljnih studija povijesnog razvoja kupališnog turizma engleskih ljetovališta, ujedno i najstarijih europskih morskih kupališta, elitnog Brightona na jugu Engleske i radničkog Blackpoola na njezinu sjeveru, Rob Shields (1991), Tony Bennett $(1983,1986)$ i John K. Walton $(1998,2000)$ daju pregled transformacija plaže u liminalnu zonu, "ugrađenu mogućnost bijega od obrazaca i ritmova svakodnevnog života" (Shields 1991:86). Prema engleskom modelu, ljetovališta su se počela graditi na obalama Sredozemlja (nastaje Azurna obala), Baltika, Atlantskog oceana (Cape May i Atlantic City kao pioniri američkih morskih odmarališta) i Pacifika (kupališni kompleks Sutro Baths blizu San Francisca te Coney Island "Meka užitaka" i morsko igralište Njujorčana). Ta prva velika ljetovališta u 19. i početkom 20. stoljeća bila su "preslike gradskoga društvenog života" i "obilježje srednjega društvenog sloja" (Lenček i Bosker 1998:250, 155). U međuratnom razdoblju razvijaju se moderni oblici dokolice (Duda 2005:33) i postavljaju temelji današnje plažne kulture: trend preplanulosti, počeci plažne modne industrije. Nova se ljetovališta grade uz egzotične tropske, najčešće otočne, plaže (Britanci na Barbadosu i Jamajci, Francuzi na Martiniqueu, Nizozemci na Curaçau, Nijemci na Ibizi i Mallorci, Amerikanci na Havajima, Kubi i Bahamima) koja postaje prototip i model "rajske plaže". U Drugom svjetskom ratu neke od najljepših svjetskih plaža ulaze kao poprišta ratnih sukoba: Dieppe, Anzio, Normandija, Salerno, Solomonsko otočje, zaljev Leyte, Iwo Jima (Lenček i Bosker 1998:217). Nakon ratnih razaranja dolazi do demokratizacije odmaranja i putovanja (Duda 2005:35) što omogućuje masovna proizvodnja, Fordova automobilska revolucija i komercijalni avionski letovi. Lenček i Bosker (1998:220-270) nastavljaju svoj povijesni pregled razvojem plaže i plažnih kultura nakon Drugoga svjetskog rata. Tijekom 50-ih godina 20. stoljeća nalikuje sigurnom i 
idiličnom dvorištu i igralištu uže obitelji, da bi već 60-ih i 70-ih pokretom "povratka prirodi" i odbacivanjem društvenih normi, materijalizma i hipokrizije postala amblematskim mjestom mladenačke popularne kulture. Uz komune na plažama započinju svoj razvoj supkulture i alternativni životni stilovi (surferi, naturisti), dok se u nekim priobalnim područjima (npr. južna Kalifornija) neka dotadašnja naselja namijenjena boravku za vrijeme odmora pretvaraju u stalna prebivališta, a život na plaži postaje svakodnevica. Rastućom urbanizacijom i litoralizacijom obale plaže su prestale biti prirodni krajolici, a neiskvareni rajevi djevičanskih plaža danas su simulacije za bogate turiste u potrazi za "autentičnošću turističkog iskustva" (Wang 1999) koje im nude putničke agencije. One su "diskurzivno i društveno konstruirani tip prirode" (Obrador Pons 2004:158).

Iz prethodno navedene skice povijesti plažnih kultura vidljivo je da je plaža "kulturna arena, prožeta pravilima, rutinama i ritualima" (Löfgren 2002:237), "kaleidoskop kulture" (Lenček i Bosker 1998:xxii). Na njoj se mogu pratiti promjene epoha, ukusa, duha vremena, ona predstavlja "sedimentaciju kulturnih tradicija" (Löfgren 2002:215).

\section{SASTOJCI PLAŽE: TRI DO ČETIRI OSNOVNA ELEMENTA, DVA KONCEPTA I TIJELO}

Plaža je postala "apodiktički primjer postmodernizma" (Rojek 1993:263) jer predstavlja samu sebe kao postmoderni krajolik različitosti, samodostatni svijet u kojem je sve prihvaćeno, "sve prolazi” i s kojeg nikada ne želimo otići, vratiti se u stvarnost. Pojavljuje se "globalna plaža" kao "bricolage rekvizita i aktivnosti iz različitih okoliša i epoha" (Löfgren 2002:215) sa stereotipnim predodžbama koje mogu odgovarati bilo kojem mjestu uz more, u bilo kojem dijelu svijeta. Kao da je "tabula rasa" na koju se tek trebaju upisati značenja (Urbain 2002:21), "simboličko mjesto gdje svaki novi val stanovnika može ostvariti svoju ideju raja" (Lenček i Bosker 1998). Prema Foucaultu (1996:10), plaže su mjesta "privremenog opuštanja". Treba ih promatrati kao heterotopije na kojima su uobičajena pravila ponašanja privremeno suspregnuta, zbiljska mjesta koja se simultano reprezentiraju, osporavaju i izokreću. Zbog nedostatka 
i neupućivanja na lokalne osobitosti i obilježja te ikonografije globalnih rajeva, plaže u turizmu, osobito onom masovnom, primjer su Augéovih nemjesta (Augé 2001).

Kao jedna od središnjih predodžbi modernog turizma i najomiljenija turistička destinacija, podložna je standardizacijama i generalizacijama iskustava plaže, što je dovelo do stvaranja "globalne ikonografije i koreografije života na plaži” (Löfgren 2002:213). Plažu čine i oblikuju more, kopno, vjetrovi i sunce. Tri su temeljna elementa globalne plaže: sunce, more i pijesak (sun, sea, sand), koji se često u literaturi o turizmu određuju i kao koncept $3 \mathrm{~S}$. On se smatra osnovom masovnog, "nediferenciranog", ekstenzivnoga kupališnog turizma koji je svoj vrhunac doživio 80-ih godina 20. stoljeća i danas se nastoji napustiti u korist intenzivnog, individualiziranijeg i specijaliziranijeg, tzv. soft turizma (Ružić 2007:71). Međutim, sunce i more i dalje su glavni turistički proizvod zemalja s obalom i otocima.

Mada plaža počiva na mnogo više "S-ova" - pogled, surfanje, seks (see, surf, sex) itd. kojima su posvećeni radovi, prostor plaže u našim imaginacijama i dalje čine ova tri osnovna elementa, uz iznimku pijeska koji u nečijim imaginativnim geografijama prepušta mjesto oblucima, šljunku ili zaravnjenim stijenama. Uz prostor plaže i plažne kulture usko su povezani koncepti tijela i života na plaži.

Osim povjesničara, sociologa, antropologa i etnologa (Urbain, Corbin, Shields, Walton, Löfgren, Duda) koji su se bavili otkrićem odmora, dokolice i početaka turizma unutar kojih su obrađivali i povijesne transformacije poimanja i viđenja plaže, suvremenim plažama se s kulturološkog aspekta najviše bavilo unutar australskih kulturalnih studija. Teoretičari kulturalnih studija John Fiske, Bob Hodge, Graeme Turner, Geoffrey Dutton 80-ih su godina raspravljali o ulozi plaže u australskoj kulturi. Nakon toga, novi val istraživačkih interesa vezanih uz australske plaže i njihove kulture pojavio se nakon 2000. godine i 27. olimpijskih igara održanih u Sydneyu na kojima je plaža predstavljena kao važan simbol australskoga nacionalnog identiteta. "Biti Australcem, znači ležati pod kancerogenim suncem, gledati druga tijela i šetati unaokolo, a potom se oprati u oceanu" (Blazey 1983:50).

Interes za proučavanje plaže i pokazivač smjera za kulturalne studije nekoliko sljedećih godina bio je rad Johna Fiskea Surfalism and Sandiotics: 
The Beach in $\mathrm{Oz}$ Culture. To je prvi, pionirski primjer kulturološke analize plaže, njezina prostora i znakova. Iako je riječ o strukturalističkoj analizi australske plaže, Fiskeov metodološki okvir univerzalno je primjenjiv na sve plaže, neovisno o geografskom smještaju. Prema Fiskeu (1983:1):

"U semiotičkom smislu plažu je moguće iščitavati kao tekst. Poput svih tekstova, plaža ima svoga autora, povijesno određen skup zajednica prakse koje su proizvele materijalne objekte ili znakove. Pod time mislim na zgrade uz plažu, kabine za presvlačenje, travnjake, šetnice, regulatorna upozorenja, prodajne kioske, stube i klupe, oznake i košare za otpatke - sve one elemente čije nam istaknute funkcionalne dimenzije ne bi smjele odvući pozornost $\mathrm{s}$ njihove značenjske dimenzije. Poput svih tekstova, i plaže imaju čitatelje. Ljudima plaže služe za pronalaženje određenih vidova značenja za sebe, značenja koja im pomažu da lakše podnesu svoj uobičajeni način života izvan plaže. Kao što je to slučaj i s drugim tekstovima, ta su značenja dijelom određena strukturom samog teksta, a dijelom društvenim karakteristikama i diskurzivnim praksama čitatelja - različiti ljudi različito se koriste plažom, u njoj pronalaze različita značenja, no postoji jedno središnje značenje koje je, u većoj ili manjoj mjeri, zajedničko svim korisnicima, od uzorne konzervativne obitelji do nekonvencionalnoga dugokosog surfera."

On smatra da je plaža danas zauzela mjesto koje su u ranijim društvima imali svetkovine i festivali. Plaža je podložna pregovaranju i različitim potrebama onih koji koriste njezin prostor u različitim dijelovima dana $\mathrm{i}$ godišnjim dobima. Na njoj se odvijaju sociokulturne dinamike u kojima se moć, identitet, značenje i ponašanje konstruiraju, iznova pregovaraju i stvaraju dodatni nepoznati elementi (Pritchard i Morgan 2000:884).

\section{TIJELO NA PLAŽI}

Plaža je "jedno od najtjelesnijih mjesta" (Webb 2003:81) gdje postajemo svjesni tijela i "u velikoj mjeri mjesto stvaranja modernog tijela" (Löfgren 2002:224). Tijelom doživljavamo sve elemente plaže i često su naša sjećanja, iskustva i osjećaji povezani s plažom u velikoj mjeri tjelesni, dio našega tjelesnog identiteta. Jednostavan užitak osjećanja sunca i pijeska 
na koži u središtu je plažne sveprisutnosti u turizmu, dok kulturne norme reguliraju tjelesnu izloženost i pristojnost nadvladava i oblikuje osjetilni okoliš (Obrador-Pons 2007:134).

Život na suvremenoj plaži postaje rad na tijelu: izlaganje tijela suncu, vodi, vjetrovima i pijesku - kao i kritičnim pogledima drugih. "Na plaži se može mnogo naučiti o tijelima, vlastitom i drugima." (Löfgren 2002:224). Golo tijelo predstavlja prirodu i ono što čovjek dijeli sa životinjama, a odjeveno tijelo predstavlja kulturu (Fiske 1983:3), na plaži je dozvoljeno da pokažemo i animalni dio sebe, dozvoljava "demokraciju tijela" (Dutton 1985:19) gdje svatko može sudjelovati u igri. Plaže, kao "zasebni prostori slobode", omogućuju posjetiteljima da privremeno ne poštuju konvencionalne norme kroz izražavanje društvenih praksi i odnosa (Moore 1996). Tijelo (privremeno) pobjeđuje u borbi prirode i kulture između društvenih ograničenja i neizraženih želja, poriva. Međutim, takvo vidljivo i javno izloženo tijelo samo je naizgled prirodno i slobodno. Tijelo na plaži jest kulturni simbol koji “priopćava mnoštvo kulturnih vrijednosti, ideja i značenja o seksualnosti, seksualnom identitetu (muškosti, ženskosti), disciplini, moralu, pristojnosti, hedonizmu, humanitarizmu, subverziji i tjelesnoj vještini”" (Booth 2001:9).

Plaža je javno vježbalište za prikazivanje tijela (Booth 2001:10), ovdje se tijelo izlaže kao "tjelesni kapital” koji se pokazuje, promatra te time podliježe evaluaciji i klasifikaciji subjekta: star - mlad, lijep - ružan, zategnut - opušten, poželjan - odbojan, itd. Time ono nije više prirodno, divlje, animalno i slobodno.

Bitno obilježje tijela na plaži jest nagost, obnaženost, odnosno stupnjevi otkrivenosti i pokrivenosti tijela. Tijela su na plaži "najvidljivija i najizloženija" (Webb 2001:85). Obnažena tijela kupača na plaži bila su uobičajena pojava sve do 60 -ih godina 18 . stoljeća kada se počinju pojavljivati različiti oblici prvih kupaćih kostima, s time da je golotinja muških kupača, pogotovo engleskih, bila prisutna čak još do polovine 19. stoljeća. Važan aspekt plažne kulture je moda, gdje su kroz povijest kupaćega kostima koji je u početku prekrivao a poslije postupno sve više otkrivao tijelo na plaži može pratiti povijest stavova o tijelu, morala i modnih trendova: od uniformnih kostima za muškarce i žene, nezgrapnih flanelskih i vunenih vrećastih haljina i hlača, preko trikoa, jednodijelnoga kupaćeg 
kostima koji je 1907. “iznijela” plivačka šampionka Anette Kellerman, muških kupaćih gaćica i havajki preuzetih iz surferske supkulture, revolucionarnoga ženskog bikinija (lansiran 1946.), monokinija/toplesa i tangi (Lenček i Bosker 1998:187-193, 210-222, 263-265). Kostim je skrivao nagost, štitio čednost, ali su od samih početaka njegov model i veličina ovisili i o tjelesnom perfekcionizmu, gdje je tjelesne nedostatke i nepoželjne tjelesne forme (debljina, starost) bolje "prekriti".

Druga odlika tijela na plaži kojoj je posvećena posebna pozornost je preplanulost. Preplanulo tijelo znak je koji poručuje da je preplanula osoba boravila u prirodi i da se vraća u kulturu s fizičkim zdravljem životinje, ali i s mentalnim zdravljem koje kontakt s prirodom unosi u neprirodnost života u kulturi (Fiske 1983:3). Kroz povijest se tamnjenje kože izbjegavalo, a bljedolikost je bila poželjna kulturna norma, standard ljepote i simbol višega društvenog statusa. Preplanulost je bila indikator fizičkog rada na otvorenome, svojstvenog nižim društvenim slojevima sve do 1920-ih kada postaje modni trend i dio kulta zdravog tijela i vitalnosti. Tako postupno dolazi do asimilacije preplanulosti u suvremeno društvo (McDermott i sur. 2003:91). Osunčani ten postaje društvena vrijednost, "utjelovljeni oblik kulturnog kapitala i koristi se kao sredstvo koje čini razliku" (Bourdieu 1986:244). Preplanulost pokazuje blagostanje, profinjenost, mogućnost dokolice, a od preplanulosti kao indikatora manualnog rada razlikuje se svojom ujednačenošću, teksturom i ravnomjernom raspoređenošću po svim (ili gotovo svim) dijelovima tijela. 'Prirodnost' preplanulosti služi oprirodnjavanju klase, dokolice i novca, jer upravo oni čine dostupnim ono prirodno (Fiske 1983).

Dva koncepta ili ideje koje podržava plaža: sloboda i demokracija. Oba su zapravo prividna i utopijska, što je već bilo vidljivo u povijesnom razvoju i predodžbama o plaži. Plaža je promatrana kao priroda i mjesto slobode, gdje načelo užitka ima istaknuto ulogu. Plaža kao "kazalište užitka" (Lenček i Bosker 1998:xx) nudi hedonističke mogućnosti, odvojenost od normi, svakodnevnih odgovornosti i rutine, podržavajući time povratak prirodi i divljini. Kao anomalijska kategorija nudi istodobno zavodljivost $i$ opasnost, mogućnost bijega i avanturu. Tijela na plaži su gola, time vraćena prirodi, dolaskom na plažu skidamo dijelove ili svu odjeću, razotkrivajući svoje tijelo, izlažući ga prirodi i ljudima. 
Ona nudi demokratske principe, na plaži su svi jednaki i anonimni, neodjeveno tijelo zamućuje prepoznavanje klase i statusa. Međutim, čak i razodjeveni i izmiješani, nismo lišeni društvene strukture i podjela. Upravo ova dva viđenja plaže najčešća su u klasičnim mitovima ali i u modernim mitovima u turizmu (Selwyn 1996). Nailazimo ih u mitu o izgubljenom raju (Cohen 2004) koji objedinjuje mit o prirodi (netaknuta, čista, osamljena izolirana mjesta) i dobrom divljaku (lokalno stanovništvo), ali i u turističkim mitovima o individualnoj slobodi i samoostvarenju te mitu o jednakosti (na plaži nestaje društveni položaj, nema podjele, svi su jednaki) (Hennig 2002). Stvarnost te prirodne slobode, demokratičnosti i egalitarizma jest činjenica da plaža zapravo "ne briše razlike nego ih privremeno ignorira" (Huntsman 2001:178), ona je mjesto na kojem je sve "regulirano, klasificirano i pažljivo razdvojeno" (Webb 2001:87).

Naturizam ili nudizam objedinjuje dva prethodno navedena koncepta - vraćanje prirodi i slobodi te stvaranje jednakosti - neraskidivo ih povezujući s golim tijelom. Započeo je kao kulturni i društveni pokret (Freikörperkultur), a postao načinom života, životnim stilom. Ideja se iz Njemačke gdje se pojavio početkom 20. stoljeća proširila u Englesku, Kanadu i SAD. Zbog drugačijeg poimanja tijela i tjelesnosti, nije nikada bio dio mainstreama plažne kulture (Green 2001:5), iako danas predstavlja bitan oblik turizma. Prema Obradoru Ponsu (2004:248), nudistička je plaža "kulturni laboratorij" koji preispituje ključne društvene definicije povezane s tijelom i svakodnevicom. Otkrivanje najintimnijih tjelesnih dijelova $\mathrm{u}$ javnosti destabilizira niz glavnih društvenim odredbi vezanih uz tijelo i svakodnevicu. Pritom otkriva neizvjesnu prirodu tijela, njegovu fluidnost, nesiguran i promjenjiv karakter.

Većina navedenih radova koji su proučavali tijelo na plaži bili su vezani uz vizualne i kognitivne odnose s plažom kao mjestom. U skladu s pomakom istraživanja s pionirskog Urryjeva "turističkog pogleda" (Urry 2002), vizualnosti i razgledavanja na "otjelovljenje" (embodiment) kao središnji pojam turističkog doživljaja (Veijola i Jokinen 1994; Johnston 2001), plaža se pokazala idealnim mjestom za analize toga "otjelovljenog" karaktera turizma, kao mjesto koje se doživljava svim tjelesnim osjetilima i aktivnim tjelesnim sudjelovanjem. 


\section{ZABRANE NA PLAŽI, JAVNI PRISTUP I OGRANIČAVANJE PRISTUPA}

Regulacija, ograničavanje i klasificiranje vidljivo je u normama ponašanja na plaži i znakovima zabrane. "Zabranjivanjem anomalijskih aktivnosti provodi se ideološko zatvaranje, stavljanjem pod kontrolu prijetnje od značenjskog viška" (Fiske 1983:6). Takva "neobična, pomno nadzirana vrsta slobode" (Webb 2001:77) temelji se na zabranama koje obuhvaćaju kontrolu i kopnenog i morskog dijela plaže, a najviše su usmjerene na tijelo na plaži. Njima se štiti sigurnost, sprečava nesreća i zagađenje, odnosno doticaj s prljavim. Na plažama nalazimo pisana i nepisana pravila i kodove, oni zapravo označuju početak stvaranja plažne kulture.

Prema pravilnicima o ponašanju na plažama te tablama sa zabranama, može se. uz povijest razvoja plažne, kupališne kulture, pratiti i povijest ideologija i ćudoređa. U najstarijim pravilima vidljiva je rodna podjela pristupa moru, pravo na kupanje u određeno vrijeme, pravo korištenja kabina za presvlačenje ili čak razgraničavanje zona na plaži. $\mathrm{Na}$ europskim plažama postojala je klasna, ekonomska i rodna podjela prostora plaža, dok je na afričkim (Durrheim i Dixon 2001), američkim (Kahrl 2012) i australskim (Huntsman 2001) plažama provođena i rasna segregacija kupača. Na plažama otoka Mauricijusa koji se u turističkim brošurama reklamira kao "kozmopolitski otok pod suncem", provodi se vrlo jasno i strogo razdvajanje turista od lokalnog stanovništva. Postoje otočne plaže namijenjene samo turistima i predstavljaju granicu za pojedine etničke skupine lokalnog stanovništva (Dobson 2007:8). Jasna ekonomska podjela na globalnim plažama prisutna je i danas. $\mathrm{Na}$ brazilskim plažama još je uvijek prisutna statusna, ekonomska podjela, gdje pripadnik visokoga društvenog sloja neće kročiti na vrući pijesak prije 14 sati (Urbain 2002:339). Životnim stilovima, aktivnostima i potkulturama (koje su ujedno i najanaliziranije unutar kulturalnih studija) koje se opiru ovakvoj vrsti kontrole - kupačice u toplesu, nudisti/naturisti i surferi - zabranjuje se ili ograničava pristup. Oni se upućuju na za njih određene plaže, područja organizirana i obilježena za takve aktivnosti ili su često protjerani na neuređene i teško pristupačne obale. 
Pravo javnog pristupa plaže je oduvijek stavljalo u fokus kao mjesta jednakosti i demokracije, gdje su svi "jednaki” i gdje svi imaju pravo pristupiti morskim obalama. Već prema prethodnim primjerima, ta je proklamirana jednakost vrlo varljiva, jednako kao i javnost prostora plaže. U jeziku pravne i ekonomske struke plaže su resursi i to u smislu prirodnog, društvenog, gospodarskog i rekreacijskog potencijala, a u Republici Hrvatskoj smatraju se pomorskim, javnim dobrom koje ne može biti predmetom prodaje i nije ni u čijem vlasništvu (Kovačić i Komać 2011:246-247). Prema tome, zatvoreni resorti koji samo svojim gostima omogućavaju pristup pripadajućim plažama, ne dozvoljavajući pristup ostalima, u Hrvatskoj ne bi smjeli postojati, niti biti izgrađeni. Gdje je granica uređenosti i opremljenosti plaža koje bi trebale zadovoljavati sve turističke potrebe? Posljednja je objava planiranog programa Ministarstva turizma koje je u suradnji s Fakultetom za menadžment u turizmu i ugostiteljstvu Sveučilišta u Rijeci pripremilo Nacionalni program upravljanja i uređenja morskih plaža prema kojem se u svrhu "marketinški atraktivnijeg načina predstavljanja plaža gostima" uvode tematske plaže. One će se grupirati u 14 kategorija kako bi određene skupine gostiju prema svojim afinitetima i sadržajima mogle odabrati kupalište za sebe. Osim očitih nedostataka ovoga prijedloga zbog pretjerane kategorizacije, pojačane komercijalizacije plaža, potencijalnih nepotrebnih intervencija $u$ prirodnom prostoru i sl. koje su već istaknuli pojedini stručnjaci (Kranjčević Batalić 2015), ${ }^{4}$ antropolozi i etnolozi, mogli bismo postaviti pitanje: a što s plažnim kulturama, povijestima i tradicijama? Hoćemo li neke od njih izbrisati i zaboraviti kako bismo neku plažu lakše svrstali u određenu kategoriju ili ćemo, kao što je povijest plažne kulture pokazala, donijeti pravilnike o ponašanju u određenom plažnom tematu? Što predstavlja "plaža kulture" i koji će to stručnjaci definirati njezine kulturološke

4 Kranjčević Batalić, Tonči 2015. "Nacionalni program pojačat će komercijalizaciju plaža i dovesti do nereda", 4. ožujka 2015. http://pogledaj.to/drugestvari/nacionalniprogram-pojacat-ce-komercijalizaciju-plaza-i-dovesti-do-jos-veceg-nereda/ (pristup 6. 3. 2015.). Prijedlog je komentirala doc. dr. Lidija Runko Luttenberger s Pomorskog fakulteta Sveučilišta u Rijeci, koja se bavila obalnim ekosistema (http://pogledaj.to/drugestvari/ nacionalni-program-pojacat-ce-komercijalizaciju-plaza-i-dovesti-do-jos-veceg-nereda/; pristup 4. 3. 2015.). 
potencijale? Kako će to neka lokalna zajednica odrediti kategoriju svojih plaža? Povući će se lokalci u zaleđe, vješto sakriti višeslojnu raznolikost svoje stoljetne svakodnevice i života uz more, a onda "namjestiti" plažu za turiste koji će prema svojim afinitetima odabirati točno određenu plažnu scenu i koreografiju iz ponuđenog repertoara "hrvatskoga sunca i mora". Ovakvi primjeri potvrđuju da je "kapitalistička proizvodnja ujedinila prostor, rušeći sve barijere između društva i njegovog okruženja. Ta unifikacija predstavlja $u$ isto vrijeme ekstenzivan $\mathrm{i}$ intenzivan proces banalizacije" te uništavanje autonomije i kvalitete samih mjesta (Debord 1967:43).

Kao studiju slučaja raznolikosti i slojevitosti plažnih kultura, tradicija, baština, ali njihove snažne isprepletenosti s razvojem turizma i turističkim kulturama, odabrali smo dubrovačka žala. Inicijalno naš interes za plaže bio je vezan uz dubrovački vaterpolo i tradiciju Divlje lige, koju smo kako etnolozi i kulturni antropolozi trebali istraživati u sklopu jedne projektne prijave suradnje između Hrvatske i Crne Gore koja, nažalost, nije realizirana. Provodile smo intervjue s igračima Divlje lige, Dubrovčanima, u Zagrebu i Dubrovniku te članovima njihovih obitelji. Već nakon prvih intervjua, shvatile smo da razgovori s našim sugovornicima i njihovi odgovori i promišljanja o plažama i plažnim kulturama nadilaze primarnu istraživačku temu. Otvorili su nam plaže kao izvrsne antropološke i etnološke terene, još uvijek vrlo slabo istražene u hrvatskoj znanosti, uz iznimku istraživanja povijesti turizma, razvoja kupališnog turizma te unutar njih samu povijest pojedinih, pretežno gradskih, kupališta i kupališne arhitekture. Dio provedenih istraživanja uključivao je i, možda u našim dosadašnjim terenskim iskustvima, "najugodniju" metodu sudioničkog promatranja. Prema Obradoru Ponsu (2004:57), plaža kao javni prostor dopušta veću slobodu u istraživanju, a njezine su glavne atrakcije relativno jednostavno započinjanje razgovora s neznancima i promatranje ljudskih tijela i ponašanja. Zbog navedenih osobina etnografske metode nisu strane nego predstavljaju središnji dio iskustva plaže. Rezultati dijela analiza dubrovačkih plaža, plažnih kultura i tradicija, kao što je Divlja liga, tek su manji segment širih započetih istraživanja kultnih hrvatskih plaža koja se provode s ciljem pripreme prijave većeg, interdisciplinarnoga istraživačkog projekta. Stoga rezultate iznesene 
ovim radom i na prethodnim kongresima ${ }^{5}$ smatramo preliminarnima, a njihovo je rano iznošenje istodobno i pozivnica kolegama koji se bave sličnim znanstvenoistraživačkim radom na povezivanje i umrežavanje.

\section{DUBROVAČKE PLAŽE}

Zašto baš dubrovačke plaže? Urbana plaža u mediteranskom, jadranskom smislu, neki je oblik proširenog "dnevnog boravka” ili "kvartovskog okupljališta", ona je preuzela ulogu koju je u povijesti imao mediteranski trg i mediteranska ulica, kala. Slijedeći Löfgrena (2002), Braudelov Mediteran danas je manje ujedinjen uzgojem maslina, vina, zajedničkom trgovinom i rimskim naslijeđem, a više turističkim paketaranžmanima, standardiziranim građevinama za odmor te zajedničkom kulturom turista u potrazi za suncem i morem. Sada već duga povijest mediteranskoga masovnog turizma stvorila je novo ujedinjenje, sinergiju prethodnih i novih predodžbi stvarajući jedinstveni "turistički Mediteran". Razvojem turizma, plaže su postale glavna mjesta turističke ponude što je utjecalo i na promjene i prilagodbe lokalnog stanovništva povezane s njihovim plažnim aktivnostima i identifikacijama. Neki su potpuno prepustili plaže turistima, povlačeći se za vrijeme turističke sezone u slabije poznate i turistima manje pristupačne uvale, dok su drugi pronašli način suživota u ljetnim mjesecima. Za analizu smo

5 Usmena izlaganja na kongresima:

a) Perinić Lewis, Ana; Maja Adžija; Joško Sindik: Kulture dubrovačkih gradskih plaža. Godišnji skup hrvatskog etnološkog društva: pre/poznavanje kulture: između konstrukcija, značenja i reprezentacija (Zagreb, Hrvatska, 5.-6. lipnja 2014.); b) Adžija, Maja; Ivana Ružić; Ana Perinić Lewis: The sun, the salt, the wild: Rethinking the heritage of Dubrovnik town beaches. Common Heritage and Technologies: Enhancement of Heritage, a Key to Development / Parmenides VII / Groupe intreracadémique pour le développement (Dubrovnik, Hrvatska, 17.-19. ožujka 2015.); c) Perinić Lewis, Ana; Ivana Ružić: Landscape of longing, a place to belong: Different representations of Dubrovnik's beaches. International and interdisciplinary conference "Movements, Narratives \& Landscapes" (Zadar, Sveučilište u Zadru, Hrvatska, 5.-7. lipnja 2015.). 
odabrali dubrovačke gradske plaže, upravo zbog njihove specifičnosti pripadanja gradu-spomeniku i vodećoj hrvatskoj turističkoj destinaciji. Uz povijesnu jezgru i mnoštvo etabliranih kulturnih proizvoda, značajan dio turističke ponude predstavljaju dubrovačke plaže i kupališta, što je u skladu s prezentacijom i doživljajem plaže kao jednim od glavnih toposa na globalnom turističkom tržištu (Löfgren 2002:213). Koncept 3S (sea, sand, sun) kao osnova masovnog, kupališnog, ljetnog oblika turizma svoj je vrhunac i u Hrvatskoj dosegao 1980-ih godina. Suvremena turistička industrija i promocija novim konceptom "više od sunca i mora" usmjerila se na stvaranje i razvoj selektivnih vrsta turizma, nudeći i stvarajući široku lepezu raznolikih sadržaja i aktivnosti koji bi trebali zadovoljiti potrebu "modernog turista" za novim, posebnosti i egzotikom. Međutim, unatoč brojnim akcijama "usprkos brojnim razvojnim inicijativama i isticanju prioriteta smanjenja sezonalnosti i razvoja drugih proizvoda, udio sunca i mora u ukupnom hrvatskom turističkom proizvodu već godinama ne pada ispod $85 \%$ fizičkog volumena" (Prijedlog strategije razvoja turizma RH do 2020. godine, 2013:8). "Sunce i more" time su i dalje dominanti hrvatski proizvodi. Većina hrvatskih, a time i dubrovačkih plaža, predstavlja se na jednak način, nudeći manje-više standardizirane popratne sadržaje i aktivnosti uz more i na moru. Opisi plaža obiluju učestalim korištenjem superlativa i preuveličavanjem pojedinih izdvojenih karakteristika. U promociji poznatijih kupališta uobičajena je praksa navođenja raznih rang-lista koje se uglavnom pojavljuju u inozemnim časopisima i na internetskim portalima namijenjenih turizmu ili putovanju, ali i u medijima uoči ili u vrijeme ljetne turističke sezone. Na tim listama se rangiraju, po često vrlo proizvoljnim kriterijima, sve "najljepše" ili "najpopularnije" svjetske plaže:

"Banje - prelijepa plaža nadomak gradskih zidina. Predstavljamo vam Banje, najpoznatiju dubrovačku plažu. Banje su izuzetno atraktivna šljunčana plaža, smještena u neposrednoj blizini Grada, nudeći time nenadmašan pogled kupačima. Sigurni smo da, već, gledajući samo ovu sliku možete zamisliti osjećaj koji nudi nazočnost na ovom jedinstvenom mjestu. Uvijek toplo i čisto more, te pogled na pučinu, drevne gradske zidine i otok Lokrum aduti su koji na Banje privlače ljude iz doslovce cijelog svijeta, te praktički ne postoji doba godine kada ćete ovu plažu zateći praznu. Ležaljke, 
suncobrani, bogat izbor pića, igrališta za odbojku na pijesku, mali nogomet i vaterpolo, nisu ni izdaleka sve što Banje mogu ponuditi.” ${ }^{\prime 6}$

"Prema izboru webstranice Skyscanner, najpoznatija dubrovačka gradska plaža Banje ušla je među prvih deset svjetskih plaža koje se ističu po svojoj ljepoti."”

Dubrovačke gradske plaže ne podržavaju simboliku i reprezentacije djevičanske, osamljene, divlje plaže jer su dio grada i gradske kulture kojoj pripadaju, zato smo pretpostavili da podliježu potpuno drugačijim reprezentacijama od tipičnih "rajskih" plaža u turističkoj promociji. Međutim, iako su dio civilizacije i modernizacije, a ne netaknute prirode, uz idilične, često tipizirane fotografije, šturi popratni tekstovi obično opisuju tip plaže, kvalitetu mora te sadržaje, usluge i aktivnosti namijenjene što udobnijem boravku turista. Povijesna gradska jezgra služi kao atraktivna pozadina koja pojačava privlačnost ponude dubrovačke obale, dok se lokalne tradicije plažnih kultura spominju samo kao zgodni kurioziteti u brendiranju destinacije. Kao da su prazna mjesta izvan prostora i vremena koja samo očekuju turiste željne sunca, mora i zabave, neovisna o obližnjim priobalnim naseljima, njihovim stanovnicima, njihovim svakodnevnim životima i kulturama.

Time se hrvatska i dubrovačka praksa turističke reprezentacije i promidžbe priklanja globalnim svjetskim trendovima. Jadranske se plaže prikazuju i opisuju u skladu sa svjetskim globalnim plažama koje najčešće nisu mediteranske plaže nego "rajske", kilometarske, najčešće pješčane američke, pacifičke i australske plaže. Ta tradicija turističkog oglašavanja započela je već 60 -ih godina 20. stoljeća u prvim jugoslavenskim promidžbenim kampanjama. Prema Yeomansu (2013:110), naglasak je bio na prodaji Jugoslavije "kao egzotičnog odredište za bogate zapadne strance i slavne ličnosti”. Jadranska obala u Hrvatskoj se uspoređivala "ne samo s

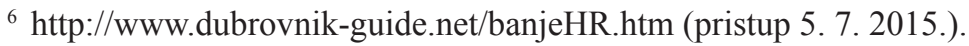

${ }^{7}$ http://www.tportal.hr/lifestyle/putovanja/28648/Dubrovacke-Banje-medu-desetnajljepsih-gradskih-plaza-na-svijetu.html (pristup 5. 7. 2015.).
} 
Francuskom rivijerom i Amalfijem, već i s Long Beachom u Kaliforniji i Copacabanom" (Yeomans 2013:110).

S druge strane, dubrovačke plaže su i lokalne, gradske plaže koje imaju svoju povijest, tradiciju i baštinu; važna su “mjesta sjećanja” ljudima koji su na njima odrastali, družili se, trenirali ili se samo rekreativno bavili pojedinim sportovima. Slojevitija i dugotrajnija od ispresijecanih i skokovitih kadrova turističkih uspomena na dokolicu, provod i avanturu.

Primjer istraživanja odnosa između lokalnih uvjeta i globalnih kulturnih procesa, turističkih reprezentacija jest rad Nataše Rogelje (2004) o ribarima i turizmu u Izoli te njezina analiza stvaranja turističkih (touristrealted) percepcija, predodžbi i mita te odnos tih okolišnih i ekonomskih stvarnosti u životu Izole (Selwyn i Boissevain 2004:25).

Izolski ribari (Rogelja 2004:293) "dio su turističkog pejzaža, a u tom pejzažu društveno su priznati, prisvaja ih se i od njih se nešto očekuje". Sudionici, vaterpolisti dubrovačke Divlje lige postaju dijelom lokalne turističke ponude samom činjenicom da se natjecanje odvija u jeku turističke sezone i to na najposjećenijim lokalitetima Dubrovnika, gradskim plažama. Divljoligaši izazivaju divljenje, uživaju poštovanje, s njima se gledatelji i lokalno stanovništvo poistovjećuju i od njih nešto očekuju - pobjedu. Ali, ova izrazito lokalna slika, u opreci je s globalnim predstavljanjem i unificiranjem turističke ponude. Turističke reprezentacije otkrivaju mrežu društvenih odnosa, stavova prema prirodi, želja, očekivanja i stvaranja novih identiteta (Rogelja 2004:294), a na primjeru izrazito lokalnog događaja, tradicionalnoga sportskog natjecanja, pokazat će upravo taj mogući vid turističke reprezentacije. Kao i u slučaju Izole i posljedicom ulaska Republike Slovenije u EU te promjene politika, i u Dubrovniku je proteklih godina došlo do promjene u turističkim smjernicama, te pojave novih oblika turizma, primjerice kruzing-turizam (Đurković 2007). Odgovaraju li predodžbe i reprezentacije turističkog mjesta iz turističkih promotivnih materijala i medija stvarnoj slici i koliko su lokalne specifičnosti reprezentirane? Dubrovnik je najprepoznatljivije turističko središte hrvatske obale i velik broj stanovnika radi u toj grani ekonomije te prilagođuje svoje životne navike turizmu i sezoni. Uključivanje ribara koje se često percipira da vode "prirodan način života" u turističku ponudu turistima koji vode "gradski način života" (Rogelja 
2004:302) čini se kao dobar i nenametljiv primjer suživota lokalaca i turista u jeku sezone.

Prije razvoja plažne kulture danas poznate dubrovačke plaže i kupališta, pogotovo ona najstarija unutar ili uz same povijesne zidine, imale su prije svega utilitarnu funkciju: bile su karantene, koristili su ih ribari, trgovci, obrtnici, pomorci i krijumčari. Bile su sve prije nego mjesta uživanja i dokolice. To je vidljivo i u podrijetlu njihova imena te nekim tradicijama koje su opstale, neovisno o turistima i drugim namjenama njihova prostora. Izdvajamo nekoliko primjera: plaža Danče, plaža Banje i plaža Kolorina/Šulić.

Rt Danče je u 15. stoljeću bio dubrovačka karantena za oboljele od gube, o čemu svjedoči i zavjetna crkvica sv. Marije od Milosti (Gospe od Danača) i groblje. Godine 1644. lazaret je premješten u istočni dio grada. Promet i trgovina s istočnim, balkanskim zemljama odvijao se preko predgrađa Ploče, a pridošlice su gledale ili prolazile pored krajolika danas svjetski poznate plaže Banje do karantenskog kompleksa Lazareta gdje su prije ulaska u grad morale provesti određeno vrijeme. Na Danče nakon preseljenja karantene u samostan dolaze sestre franjevke od Bezgrešnog začeća i tradicionalno zvonima stoljećima pozdravljaju pomorce i brodove koji prolaze pored dubrovačkih zidina. Ispod tvrđave Lovrijenac nalazi se kupalište Šulić, poznato i kao Kolorina. U imenu ovoga gradskoga kupališta ostalo je i prezime dubrovačke obitelji, vlasnika uvale. Područje Pila i Kolorine bilo je glavna gradska luka do 12. stoljeća. Poslije su na mjestu današnje plaže Šulić bile prostorije za bojenje tkanina (tal. colore - boja, tal. colorire - bojati, slikati) pa se i danas taj dio zove Kolorina (Lucianović 2012).

\section{RAZVOJ DUBROVAČKE KUPALIŠNE KULTURE, TRADICIJE I BAŠTINE}

Navedene su dubrovačke lokacije imale svoje značajno mjesto u povijesti grada, potvrđujući plažu kao mjesto "sedimentacije" različitih kulturnih praksi. Pojavom i razvojem mode kupanja u moru, one se pretvaraju u najstarija javna gradska kupališta i mjesta na kojima se mogu pratiti počeci povijest dubrovačke plažne kulture, povijest dubrovačkog turizma te razvoj vodenih sportova, osobito vaterpola. 
Za razliku od vrlo dobro istražene povijesti kupališnog turizma kvarnerskog područja i Opatije, istraživanja dubrovačkoga kupališnog turizma i kulture dubrovačkih plaža ostala su na marginama proučavanja povijesti hrvatskog turizma. Pojavom turizma krajem 19. stoljeća Dubrovnik je prvo bio morsko, zimsko lječilište te razvijao zdravstveni turizma temeljen na mediteranskoj klimi i termalnim izvorima, a ne moru. Ljekoviti izvor mineralne vode Smrdećevo u Mokošici bio je izvrsna podloga za razvoj zdravstvenog turizma pa je 1905. otvoreno lječilište Thermoterapia koje je pružalo usluge sumporne blatne i parne kupelji, kao i masažu poput suvremenih kupališta svoga vremena (Benić Penava i Matušić 2012:55). Nakon Prvoga svjetskog rata razvija se ljetni, kupališni turizam, u lokalnim novinama pojavljuju se oglasi o iznajmljivanju kuća ili soba za odmor "na mjestu izvrsnom za kupanje" (Šubić 2008:74-75). U međuratnom razdoblju Dubrovnik stječe status poznatoga turističkog središta. Turistički promet je porastao za 149,6\% u razdoblju od 1925. do 1938. godine, a od ukupnog broja turista koji su posjetili Dubrovnik i njegovo uže područje 1938. godine bilo je 70,6\% stranih posjetitelja. U okviru turističkog prometa prema broju dolazaka dominirali su Česi i Slovaci, te Austrijanci i Nijemci (Benić Penava i Matušić 2012:81). Posebnost i privlačnost Dubrovnika kao elitnog odmarališta bile su prepoznate u Kraljevini SHS. Politički krugovi i bogati dio stanovništva nalazili su sredstva za dolazak i uživanje u gradu, dok je prometna izoliranost samo na manje imućne imala ograničavajući učinak. Stoga ne čudi podatak da je u međuratnom razdoblju održano ukupno 13 međunarodnih sastanaka, dok je skupova, sastanaka i pregovora, čiji su sudionici bili s prostora međuratne Jugoslavije, bilo daleko više, a često je riječ o okupljanjima političke, intelektualne i kulturne elite onoga vremena (Franić 1979, prema Benić Penava i Matušić 2012:80). Taj će status mondenog, elitnog ljetovališta i vodeće turističke destinacije zadržati do danas.

Dolaskom turista pojavljuju se pravila koja se odnose na ponašanje na plažama i kupanje u moru. Dubrovačka općinska uprava u lipnju 1920. izdaje "Kupališni red”, a 1925. godine izlazi “Općinski pravilnik ponašanja na dubrovačkim kupalištima” (Perić 1983:138; Lucianović 2012:8-10). Iz pravila o rasporedu i vremenu kupanja u moru, o korištenju prostora i kupališnih građevina na plažama vidljiva su rodna i klasna razdvajanja. Izgradnjom dubrovačkih hotela u hotelskim brošurama pojavljuju se 
i prve napomene da plažu mogu koristiti isključivo hotelski gosti. Na dubrovačkim se plažama oblikuje kupališna moda, a o povijest razvoja kupaćih kostima svjedoče mnoge fotografije i fotografske razglednice. Od graditeljske kupališne baštine danas je sačuvana samo Kupališna zgrada Dubrovačkoga kupališnog i hotelskog društva smještena u sjeveroistočnom dijelu uvale Srebreno, Župa dubrovačka. ${ }^{8}$

Odmah nakon otvaranja javnih dubrovačkih kupališta bila je vidljiva njihova otvorenost prema turistima ili zatvaranje za potrebe lokalne zajednice. Primjerice, kupalište Šulić bilo je isključivo za građanstvo, a domaći i strani posjetitelji morali su plaćati ulaznicu, Danče postaje omiljeno kupalište omladine koja se vratila iz Prvoga svjetskog rata (Lucianović 2012:30).

Dubrovčani su bili vezani uz svoje plaže, naročito djeca i mladi koji, posebice u ljetnim mjesecima, na njima osnivaju svoje republike i kraljevstva. Najpoznatije su Republika Danče, Republika Porporela, Kraljevina Pile, Kraljevina Banje, Kraljevina Kolorina. Svaka od njih imala je svoja pravila, statut, boje i himnu, a nešto poslije i svoju vaterpolsku momčad (Mladinić 2013:4). Nakon Drugoga svjetskog rata, izlaskom iz kriznoga ratno-poratnog razdoblja eksproprijacije, nacionalizacije imovine, podruštvovljenja gospodarstva, samoupravljanja i socijalnoga, radničkog turizma, 60-ih i 70-ih godina intenzivno se investira u turizam i brodarstvo. Zbog toga što se "žarište političke pozornosti sa socijalnoga premjestilo na komercijalni turizam" (Duda 2013:60) ponovno se vraćaju gosti iz zapadnih zemalja.

Ostvareni društveni proizvod od 1968. do 1975. bio je visoko iznad prosjeka Hrvatske, do više od 62\% iznad prosjeka BDP po stanovniku (Kobašić 2006:247). Svoje je "zlatne turističke godine" Dubrovnik doživio 80-ih godina 20. stoljeća, o čemu najbolje svjedoči podatak da je 1985.

8 Istraživanja i arhivski rad u dubrovačkim arhivima vezan uz povijest dubrovačkih kupališta provodi Ivana Ružić, doktorandica na poslijediplomskom doktorskom studiju Povijest stanovništva Sveučilišta u Zagrebu i Dubrovniku, Zavoda za povijesne znanosti HAZU. U suradnji s autoricama ovoga rada, do kraja ove godine planira se objava preliminarnih rezultata istraživanja u publikacijama i kongresnim izlaganjima. 
godine ostvaren i turistički rekord stoljeća, sa 905150 posjeta i 5868000 noćenja (Kobašić 2006:247). Dubrovnik uživa status turističke metropole, dobiva zračnu luku Ćilipi, povezuje se Jadranskom magistralom, a izgrađuju se nove stambene četvrti te hotelska naselja na Lapadu (Babin kuk). Plaže i kupališni turizam u središtu su turističke ponude, a Dubrovnik uz kultna gradska kupališta širi ponudu kupališnog turizma na Lapadskim plažama te se otvara naturističkom turizmu kroz FKK (Freikörperkultur) kupališta, npr. Cava, Beterina (Mlini), Plat tena otočiću Lokrumu. Prema iznesenim iskazima (Green 2001:1-2), pojedini su turisti iz zapadnih zemalja doživjeli prvi susret s "prijateljskom" i pristupačnom nudističkom plažom upravo u Dubrovniku (Mlini). ${ }^{9}$

Zbog pripadanja specifičnom, zaokruženom povijesnom gradu, najstarije dubrovačke plaže su kao živo gradsko "tkivo" bile kulturne i životne pozornice. Zbog Dubrovačkih ljetnih igara utemeljenih 1950. godine Dubrovnik postaje stjecište uglednih umjetnika te destinacija kulturnog turizma. Oaza unutar standardizirane jugoslavenske ljetne turističke ponude. Zbog specifičnosti DLJI-a koje koriste prostor staroga grada za predstave i koncerte, dubrovačke plaže mjesta su festivalskih događanja (primjerice, izvedba Shakespeareove Oluje na plaži Danče 1962. u režiji Koste Spajića). Time se dubrovačke plaže kao dio festivalskoga grada potvrđuju kao krajolici prizorišta značajni za imaginarije koje festivali stvaraju (Gilmore 2010; Kozorog 2012).

\footnotetext{
9 "As I recall, it was on our very first day at Mlini, a short boat trip from Dubrovnik, that I discovered the difference between the 'textile' beach and the FKK beach, both of which were comfortably close to our pension-style hotel. The textile beach was actually labelled 'textile beach', and I wasn't sure why at first. It faced the hotel, a road and a cafe away. It was reasonably well populated by the predictably pale-skinned tourists reclining on towels and lounges. A sign reading 'FKK' pointed to the left, along a path that disappeared from sight at the crest of the hill. We followed the path. The path led over a rise and around a bend. That bend revealed a pebble and sand beach upon which all the people were bare. It was maybe a hundred metres or so from the textile beach, but it felt like a different country. The beach was fully serviced-it had a cafe/bar/restaurant, toilets, sun umbrellas, table and chairs on a balcony overlooking the beach, and waiters in white shirts and black trousers. I was later to discover that this level of comfort was a specific outcome of history, geography, and economy. Amazing as it may seem now, my partner and I stripped off without hesitation" (Green 2001:1-2).
} 
Dubrovačka turistička ponuda uvijek je podrazumijevala goste veće "platežne moći”, uzdižući se time iznad ostalih uspješnih jadranskih turističkih centara.

Nakon razdoblja Domovinskog rata (1991.-1995.) Dubrovnik i okolica bili su pogođeni destrukcijom i ratnim stradanjem. Dubrovačke plaže ušle su u povijest kao mjesta izravnih ratnih stradanja:

"Sjećate li se 3. kolovoza 1995.? Ja ga se sjećam dobro i bolje nego što bi htjela. Toga dana nakon dugog primirja na Veliki Zaton, točnije na stijene na poluotoku pale su dvije granate u popodnevnim satima."10

U granatiranju plaže na kupanju su poginule tri mlade osobe.

$\mathrm{Na}$ dulji je rok bilo izgubljeno turističko tržište koje se tek počelo oporavljati 1997. godine. Dubrovnik je uspio povratiti svoj status vodeće turističke destinacije. Njegove su plaže postale mjesta novih "igara" podizanja profita i turističke reprezentacije s ciljem komercijalizacije. Dolazi do prije spomenutog forsiranja unifikacije plaža (klasifikacija, tematizacija i zoniranje), lošeg upravljanja plažama te dodjela plažnih koncesija pri kojima koncesionari okupiraju velik dio prostora plaže nudeći previše različitih i nepovezanih zabavnih i rekreativnih sadržaja.

Zanimala nas je današnja povezanost Dubrovčana s njihovim kupalištima i plažama te kako se snalaze s turistima na svojim omiljenim kupalištima i morskim okupljalištima. Provele smo kvalitativna istraživanja koja su potvrdila snažno postojanje plažnih republika i kraljevstava unutar nekadašnje Dubrovačke Republike:

“Mi nismo u Dubrovniku samo podijeljeni po kvartovima, ko' u Zagrebu, nego i po plažama. Tako su i te gradske plaže imale svoju grupu ljudi, oni su čak to zvali republike, kraljevine, carstva ili ne znam što." (Ivo, oko 50 godina starosti, plaža Bellevue)

Pripadnost određenoj plaži i kupalištu jednako je snažna kao i kvartovska i generacijska pripadnost, a u pojedina se društva teško ulazilo:

10 “Sjećate li se 3. kolovoza 1995.?", http://dubrovniknet.hr/novost.php?id=14206\#. VajBfqTtlHw (pristup 2. 7. 2015.). 
"Na Dančama se svi znaju od sedam do sedamdeset ... i svak zna skoro sve o svakome i treba godina da prođe koja da se uklopiš." (Miho, oko 30 godina starosti, plaža Danče);

"Ja sam zaobilazila mondene plaže jer nisam imala dovoljno velika prsa, nisam imala dovoljno veliki broj da bi bila primijećena [smijeh] pa sam birala neka druga mjesta. Mora si imati dovoljno veliki broj, dobru marku kostima i morala si promijeniti puno momaka i to da su što poznatiji." (Mare, oko 40 godina starosti);

"Kad sam se prvi puta spustila u Šulića, odmah sam primijetila gospođe koje su zauzele najljepši dio plaže. Lijevi betonirani dio, prije skalica. Na plažu dolaze svaki dan točno u 14 sati, kartaju za plastičnim stolom, pod velikim suncobranom, oko 17 sati skuhaju kavu, direktno na plaži. Da, to je njihov dnevni boravak na otvorenom. A svi mi, ostali, smo gosti." (Sanja, oko 30 godina starosti, plaža Šulić)

Na plažama su se, osobito onim unutar ili blizu gradske jezgre, razvijale neke, sada već tradicionalne aktivnosti, slobodno se vrijeme provodilo u kartanju i nekim momčadskim sportovima kao što su vaterpolo, picigin, "glavomet", u novije vrijeme mali nogomet i plivački maratoni. Neka su kupališta imala izraženiji identitet (primjerice Danče, Porporela) od ostalih. Iz razgovora je vidljivo kako naši dubrovački sugovornici dobro poznaju gotovo sve plaže, uvale i kupališta u Dubrovniku i okolici, provode slobodno vrijeme ili se rekreiraju na više njih, kako nam je rekla Mare (oko 40): "Biraš plažu prema dobi i potrebama." Međutim, većina Dubrovčana ima je neku "svoju" omiljenu plažu uz koju je snažnije vezana, živi u njezinoj blizini ili na nju radije navraća. U dosta slučajeva neka je plaža taj status stekla kao "mjesto sjećanja" povezano s odrastanjem, obitelji, generacijskim druženjem, zaljubljivanjem:

"Kupale smo se u srednjoj na Dančama jer su tamo bili vaterpolisti, kibicali smo vaterpoliste, očijukali. Igrali na karata." (Kate, oko 30 godina starosti);

"Sjećam se, mene je otac prvi put doveo na Danče. On se tamo kupao. Kako mi živimo na drugom dijelu grada, najprije smo se kupali na 
Banjama. I tek sam s 5, 6 godina došao na Danče. I otac se kupao na Dančama." (Ante oko 30 godina starosti, plaža Danče)

Time je potvrđeno da "lokaliteti postaju značenjski konstruirani kroz društvenu praksu i emotivnu vezanost” (Čapo i Gulin Zrnić 2011:29).

\section{DIVLJA LIGA - LOKALNA SPORTSKA TRADICIJA DUBROVAČKIH KUPALIŠTA I PLAŽA}

Upravo iz takve vezanosti uz plaže i plažne kulture kupanja i plivanja, posebno snažno su se razvili dubrovački vodeni sportovi, među kojima je najpoznatiji vaterpolo. Vaterpolo se smatra "najdubrovačkijim sportom", a nazivaju ga još i “šestom dubrovačkom tvrđavom” (Bauer i sur. 2010:246). Kultni, trofejni dubrovački vaterpolski klub Jug početke svojeg razvoja veže upravo uz plažu Danče koju smatra svojom "kolijevkom”. Danas je u Dubrovniku jednako kao igranje profesionalnog vaterpola ili bivanje strastvenim jugašem, bitno sudjelovati u "Divljoj ligi" - amaterskom vaterpolskom natjecanju dubrovačkih uvala i kupališta. Ovo se prvenstvo neprekinuto održava od 1983. godine od kraja srpnja do polovine kolovoza. Turnir je izrazito lokalnoga karaktera, što se očituje i u najbitnijem preduvjetu za samo sudjelovanje - dubrovačkom podrijetlu. Divlja liga postala je dubrovačka tradicija i bitan dio kolektivnog identiteta stanovnika grada Dubrovnika i dubrovačke okolice. Primjerice, 2005. godine njemački Bild uvrstio je Divlju ligu među sto jedinstvenih svjetskih sportskih događaja koje nećete pronaći nigdje drugdje u svijetu (Mladinić 2013:4). Od svojih je početaka snažno povezana s gradskim glasilima, posebno s Dubrovačkim vjesnikom, a sportski novinari tradicionalno su njezini vodeći organizatori (Jadran Kapor, Tonči Vlašić). Njezina se povijest, ekipe, rezultati utakmica pamti, bilježi i prati, danas pretežno preko internetskih portala, među kojima se svojom informativnošću i profesionalnošću posebno ističe www.dance.hr. Pravilnikom regulirano nadijevanje imena divljoligaškim ekipama obavezuje ih da ime vežu uz lokalitete kupališta kojem pripadaju i koje predstavljaju. Divljoligaške utakmice popraćene su navijačkom podrškom obitelji i prijatelja. Dok se sportski dvoboj među vaterpolskim ekipama odvija u moru, kreativni navijački dvoboji jednako 
su strastveni. Osmišljavaju se kostimi, navijački rekviziti, pjesme, čak i koreografije. Navija se s brodova i za tu prigodu unajmljenih replika povijesnih dubrovačkih karaka. Time divljoligaške utakmice unose karnevalsku i ludičku atmosferu na dubrovačke plaže usred turističke sezone, uz iznimku da za razliku od karnevala turisti mogu promatrati, ali ne i aktivno sudjelovati u ovoj živoj, ljetnoj tradiciji kojom se plaže potvrđuju kao mjesta pripadanja i identifikacija lokalnog stanovništva: ${ }^{11}$

“... bude stranaca. Vide da se nešto događa, ambijent je lijep, sjednu, gledaju, ne bude im ništa jasno. Zadnji put kad sam bio, do mene su sjedali nekakvi Nizozemci, ne sjećam se, Nizozemci ili Belgijanci, i gledaju, valjda su odgledali pola utakmice i onda su me tek pitali što to oni gledaju [smijeh]". (Frane, oko 50 godina starosti, Danče).

Na dubrovačkim plažama u ljetnim mjesecima dolazi do suprotstavljanja, smjenjivanja i supostojanja dviju predodžbi i reprezentacija plaže. Turisti ih zaposjedaju kao mjesta realizacije fantazija, želja i očekivanja, dok Dubrovčani i vaterpolisti rekreativci na njima žive svoju svakodnevicu, stvaraju društvene interakcije i potvrđuju svoje identitete.

Pobjednici turnira dobivaju pehar koji uz ostale uspomene (potpisanu loptu, kapice i sl.) najčešće čuvaju u kafiću na plaži kojoj pripadaju te uživaju poseban status u pobjedničkoj godini:

"Velika je čast i sudjelovat. Ja znam, kad smo mi prvi put osvojili Divlju ligu, meni su prijatelji govorili, da bi oni cijelo ljeto hodali po Stradunu: 'Svi gledajte! Osvojio sam Divlju ligu!'” (Luka, oko 30 godina starosti, Danče)

Divlja liga se temelji na volonterstvu i entuzijazmu, a divljoligaši uređuju i održavaju morska vaterpolska igrališta (golove, plutače). U posljednje vrijeme njihova briga i organizirane akcije usmjerene su i na obranu prava "na stalan, nesmetan i neograničen kopneni pristup morskoj obali i moru" te na zaštitu kolektivnih interesa građana "u pravu na

${ }_{11}$ Perinić Lewis je sa suautorima posebno analizirala Divlju ligu i njezine potencijale za oblikovanje kulturnoga turističkog proizvoda i turističkog branda u radu Šiljeg i sur. 2015. 
sigurnost plivanja i kupanja u moru" (Udruga Divlja liga, 2014). ${ }^{12}$ Te su akcije povezane s nezakonitim privatnim ograđivanjima ili ograničenjima koje nameću hoteli i koncesionari na plažama, one nisu samo građanski protesti nego uključuju i uklanjanje nepoželjnih prepreka. Izdvajamo jedan recentniji primjer uklanjanja zapreka javnom pristupu plaži gdje su volonteri predvođeni gospodinom Igorom Legazom napravili intervenciju u obliku pravoga građevinarskog zahvata:

"Udruga Divlja liga vaterpolo, kako je najavljeno, jutros u 8 sati započela je radove na probijanju otvora u zidu koji kupalište hotela Splendid dijeli od onoga ispod Vile Banac. Predsjednik Udruge uz pomoć nekoliko članova i volontera namjeravao je izgraditi vrata na volat širine jednog metra i visine nešto više od metar i pol kako bi osigurao neometani pristup popularnoj plaži ispod vile u vlasništvu dubrovačkog bogataša Braslava Turčića."'13

Ovi su dubrovački primjeri možda snažne potvrde u Hrvatskoj još nedovoljno artikuliranog i još uvijek neizrečenog straha da će budućnost javnog i slobodnog pristupa moru biti zatvarana u ime turizma i zarade.

Nadubrovačkimsegradskimplažamasastajupredodžbe,reprezentacije i imaginariji globalne i lokalne plaže. Turistička industrija, u vječnoj potrazi za povećanjem profita, dubrovačke plaže pretvara u slike i umjetne simbole koji ne odgovaraju stvarnim fizičkim krajolicima. Unatoč potrazi za novim oblicima turizma (kulturni, kreativni), prikazi plaža ostali su u tipiziranim i standardiziranim instant-paketima ponude "sunca i mora", ignorirajući prebogatu jedinstvenost i raznolikost dubrovačkih plaža i plažnih kultura. Posebnosti i specifičnosti lokalne kulture koje su danas najvrjedniji elementi u suvremenim turističkim promocijama jer izdvajaju određenu destinaciju i čine je jedinstvenom u odnosu na ostale, izostavljene su u promociji dubrovačkih plaža. Umjesto da se pokažu svi sedimenti povijesti plaža i plažne kulture, oni se prekrivaju uvezenom egzotikom tropskog

\footnotetext{
12 Preuzeto s internetske stranice: http://www.divljaliga.eu (pristup 13. 3. 2014.).

13 Preuzeto s internetske stranice: http://dubrovackidnevnik.hr/vijesti/grad/legaz-zapoceogradnju-vrata-na-titovoj-vili-foto-video (pristup 20. 5. 2014.).
} 
pijeska, palmama, havajskim dekorativnim elementima ... Lokalna plaža kao dio svakodnevnih potreba i aktivnosti lokalnog stanovništva nalazi svoj put preživljavanja ljeta, ipak prepuštajući prve redove uz more "dragim gostima". Odabirući malo izmještenija mjesta ili manje "popularno" vrijeme te izbjegavajući turističke mase koje odmaraju uz njihova žala. No, s druge strane, lokalne tradicije i prakse, kao vaterpolske utakmice Divlje lige, izići će iz standardizirane slike turističkog Dubrovnika i iznijeti duh lokalne plažne tradicije i kulture "ljudi od mora" te živu dubrovačku atmosferu, ne trudeći ih se pretjerano objašnjavati ili promovirati. One su potreba osnaživanja zajedništva i potvrđivanja lokalnih identifikacija u ljetnim mjesecima kada je većina Dubrovčana aktivno i gotovo cjelodnevno uključena u neki oblik turističke djelatnosti.

Unatoč činjenici da su plaže iznimno plodan tereni za etnološka i antropološka istraživanja, začudan je izostanak sustavnijih istraživanja i analiza hrvatskih plažnih kultura, reprezentacija i identifikacija. Zato na kraju donosimo riječi antropologa na plaži o plaži, uz poziv hrvatskim kolegama etnolozima i antropolozima "Hajdemo na plažu!":

“... danas su nam uskraćene i one čari koje ja nalazim u moru. Poput životinje čiji oklop s godinama postaje sve deblji i stvara oko njenog tijela nepropusnu koru koja više ne dopušta koži da diše, što samo ubrzava starenje, većina evropskih zemalja dopustila je da njihove obale pretrpaju vile, hoteli i kockarnice. Umjesto da nam, kao nekad, dočarava trenutke oceanske usamljenosti, obala je postala nekakva fronta na kojoj ljudi povremeno mobiliziraju sve svoje snage da bi jurišali u osvajanje slobode čiju čar bi željeli ugrabiti pod uvjetom da se ne liše upravo onoga što je uništava." (Lévi Strauss 1960:233)

\section{LITERATURA}

AUGÉ, Marc. 2001. Nemjesta: uvod u moguću antropologiju supermoderniteta. Karlovac: Naklada Društva arhitekata, građevinara i geodeta.

BAUER, Dean; Ante DRPIĆ, Igor DUVNJAK, Anton FILIĆ, Zlatko KARLO, Zdenko JAJĆEVIĆ, Ivo MIKULIČIN, Pero OGURLIĆ, Ante VLAŠIĆ, Bogdan VUJINA. 2010. Stoljeće hrvatskog vaterpola, gl. ur. Dean Bauer. Zagreb: Hrvatski vaterpolski savez. 
BENIĆ PENAVA, Marija i Đuro MATUŠIĆ. 2012. "Razvoj smještajnih kapaciteta na dubrovačkom području između dva svjetska rata: Polazište za razvoj suvremenog turizma". Acta Turistica, 24/1:61-86.

BENNETT, Peter. 1996. Blackpool Pleasure Beach: A Hundred Years of Fun. Blackpool: Blackpool Pleasure Beach.

BENNETT, Tony. 1983. "A Thousand and One Troubles: Blackpool Pleasure Beach". U Formations of Pleasure, ur. Tony Bennett, Lucy Bland, Victor Burgin, Tony Davies, J. Donald, Simon Frith. London: Routledge.

BENNETT, Tony. 1986. “Hegemony, Ideology, Pleasure: Blackpool”. U Popular Culture and Social Relations, ur. Tony Bennett, Colin Mercer i Janet Wollacott. Milton Keynes: Open University Press, 135-154.

BERNARDES, Joana Duarte. 2010. "Limit and Utopia: Revisiting the Beach as a Threshold". Journal of Visual Art Practice, 9/3:219-230. DOI: 10.1386/ jvap.9.3.219_1

BLAZEY, Peter. 1985. “Australian 31 December 1983”. U Sun, Sea, Surf and Sand: the Myth of the Beach, ur. Geoffrey Dutton. Melbourne: Oxford University Press, 50.

BONNER, Frances, Susan MCKAY i Alan MCKEE. 2001. "On the beach". Continuum, 15/3:269-274. DOI: 10.1080/10304310120086768

BOOTH, Douglas. 2001. Australian Beach Cultures: The History of Sun, Sand, and Surf. London: Frank Cass Publishers.

BOURDIEU, Pierre. 1986. "The forms of capital". U Handbook of Theory and Research for the Sociology of Education, ur. John G. Richardson. New York - Westport London: Greenwood Press, 241-258.

COHEN, Erik. 2004. "The Pacific islands from utopian myth to consumer product". U Contemporary tourism; Diversity and change, ur. Erik Cohen. Amsterdam: Elsevier, 249-274.

CORBIN, Alain. 1994. The Lure of the Sea - The Discovery of the Seaside in the Western World 1750-1840. Berkeley - Los Angeles: University of California Press.

CVITANOVIĆ, Alfonso. 2002. Geografski rječnik. Zadar: Hrvatsko geografsko društvo.

ČAPO, Jasna i Valentina GULIN ZRNIĆ. 2011. “Oprostornjavanje antropološkog diskursa. Od metodološkog problema do epistemološkog zaokreta”. U Mjesto, nemjesto. Interdisciplinarna promišljanja prostora i kultura, ur. Jasna Čapo, Valentina Gulin Zrnić. Zagreb: Institut za etnologiju i folkloristiku - Ljubljana: Inštitut za antropološke in prostorske študije, ZRC SAZU, 9-65

DANN, Graham. 2002. "La Serenissima: Dreams, Love and Death in Venice". U Literature and Tourism: Reading and Writing Tourism Texts, ur. Hans Andersen i Mike Robinson. London: Continuum, 239-278.

DEBORD, Guy. 1967. Društvo spektakla. http://anarhisticka-biblioteka.net/library/guydebord-drustvo-spektakla.pdf; pristup (12. 7. 2015.). 
DOBSON, Reena. 2007. "Beaches and Breaches: Articulations and Negotiations of Identity, Ethnicity and Cosmopolitanism in Mauritius - 'The Most Cosmopolitan Island Under the Sun"'. Limina: A Journal of Historical and Cultural Studies Special Edition 'On the beach', 1-11.

DUDA, Igor. 2005. U potrazi za blagostanjem. O povijesti dokolice i potrošačkog društva u Hrvatskoj 1950-ih i 1960-ih. Zagreb: Srednja Europa.

DUDA, Igor 2013. "O radnika do turista: prava, želje stvarnog socijalno turizma u jugoslavenskom socijalizmu”. U Sunčana strana Jugoslavije. Povijest turizma u socijalizmu, ur. Hannes Grandits i Karin Taylor. Zagreb: Srednja Europa, 55-87.

DURRHEIM, Kevin i John DIXON. 2001. "The role of place and metaphor in racial exclusion: South Africa's beaches as sites of shifting racialization". Ethnic and Racial Studies, 24/3:433-450. DOI: 10.1080/01419870020036738

DUTTON, Geoffrey. 1985. Sun, Sea, Surf and Sand: the Myth of the Beach. Melbourne: Oxford University Press.

ĐURKOVIĆ, Vlaho. 2007. "Razvoj Dubrovnika kao luke ticanja u kruzing-turizmu i projektni razvoj luke Dubrovnik”. Naše more, 54/1-2:32-41.

FARIČIĆ, Josip. 2006. “Obala - prostor kontakta i konflikta”. U Akademik Josip Roglić $i$ njegovo djelo - Zbornik radova, ur. Mate Matas. Split - Zadar - Zagreb: Hrvatsko geografsko društvo, 269-298.

FISKE, John. 1983. "Surfalism and Sandiotics: The Beach in Oz Culture". Australian Journal of Cultural Studies, 1/2:120-149.

FOUCAULT, Michel. 1996. “O drugim prostorima” (prev. Stipe Grgas). Glasje, 6:8-14.

FRANIĆ, Augustin 1979. Kongresni turizam u Dubrovniku razvoj-značajke-perspektiva. Dubrovnik: Privredna komora za Dalmaciju Ispostava Dubrovnik.

FRANKLIN, Adrian. 2003. Tourism: An Introduction. London - New Delhi: Thousand Oaks, SAGE Publications Ltd.

GAĆE, Ivan. 2011. Održivo upravljanje plažama - studij slučaja Grad Split. Split: Ekonomski fakultet Sveučilišta u Splitu. Diplomski rad (mentor: prof. dr. sc. Maja Fredotović).

GILMORE, Lee. 2010. Theatre in a Crowded Fire. Ritual and Spirituality at Burning Man. Berkeley - Los Angeles - London: University of California Press.

GREEN, Lelia. 2001. "Hiding Behind Nakedness on the Nude Beach". Australian Journal of Communication, 28/3:1-10.

GREEN, Lelia. 2003. "Perfect Imperfection: Feeling Cool on the Nude Beach". U Some Like It Hot: The Beach As A Cultural Dimension, ur. James Skinner, Keith Gilbert, Allan Edwards. Sports, Culture \& Society, Volume 3. Oxford: Meyer\&Meyer Sport, $110-128$.

HANNAVY, John. 2003. The English Seaside in Victorian and Edwardian Times. Oxford: Shire Library. 
HENNIG, Christoph. 2002. "Tourism: Enacting modern myths". U The Tourist as a Metaphor of the Social World, ur. Graham Dann. Wallingford: CAB International, $169-187$.

HOPKINS, Jeffrey. 1998. "Signs of the Post-Rural: Marketing Myths of a Symbolic Countryside". Geografiska Annaler, 80/2:65-81. DOI: 10.1111/j.04353684.1998.00030.x

HUNTSMAN, Leone. 2001. Sand in Our Souls: The Beach in Australian History. Melbourne: University Publish.

JOHNSTONE, Lynda. 2001. "(Other) bodies in Tourism Studies”. Annals of Tourism Research, 28/1:180-201. DOI: 10.1016/S0160-7383(00)00012-8

KAHRL, Andrew W. 2012. The Land Was Ours: African American Beaches from Jim Crow to the Sunbelt South. Cambridge, Mass.: Harvard University Press.

KOBAŠIĆ, Antun. 2006. “Uspješna i krizna razdoblja u dubrovačkom gospodarstvu u 20. stoljeću”. Naše more, 53/5-6:244-250.

KOS, Mirjana i Julija LOZZI BARKOVIĆ. 2009. Kvarnerska kupališna baština: nestala kupališta s kraja 19. i početka 20. stoljeća. Opatija - Rijeka: Hrvatski muzej turizma, Državni arhiv u Rijeci.

KOVAČIĆ, Mirjana i Ante KOMAĆ. 2011. "The Issues of Beach Management in Croatia, with Emphasis on Zadar County”. Naše more, 58/5-6:244-255.

KOZOROG, Miha. 2012. "Primjer slučajnog turizma: društveni i prostorni čimbenici festivalskog turizma u Tolminu u Sloveniji”. Studia ethnologica Croatica, 24:87106.

LENČEK, Lena i Gideon BOSKER. 1998. The Beach: The History of Paradise on Earth. New York: Viking Penguin Group.

LÉVI-STRAUSS, Claude. 1960. Tužni tropi. Zora: Zagreb.

LÖFGREN, Orvar. 2002. On Holiday - A History of Vacationing. Los Angeles: University of California Press.

LUCIANOVIĆ, Lukša. 2012. Dubrovačke plaže - nekad. Dubrovnik: Udruga za očuvanje tradicije dubrovačkog turizma "Dubrovački izlog".

MACCANNELL, Dean. 1976. The Tourist. A New Theory of the Leisure Class. New York: Schocken Books.

MCDERMOTT, Liane, Mike EMMISON, John LOWE 2003. "Changing Discourses and Popular Attitudes to Suntanning". U Some Like It Hot: The Beach As A Cultural Dimension, ur. James Skinner, Keith Gilbert, Allan Edwards; Sports, Culture \& Society, Volume 3. Oxford: Meyer\&Meyer Sport, 91-109.

MLADINIĆ, Nardi. 2013. Vaterpolska Divlja liga u Dubrovniku. Kineziološki fakultet Sveučilišta u Zagrebu. Diplomski rad (mentor: prof. dr. sc. Nada Grčić-Zubčević). 
MOORE, Henrietta L. 1996. Space, Text, and Gender: An Anthropological Study of the Marakwet of Kenya (Mappings: Society, Theory, Space). New York: Guilford Press.

OBRADOR PONS, Pau. 2004. Tourism as Dwelling: An Ethnography of the Practices, Bodies and Places of Mass Tourism in Menorca. PhD thesis, University of Durham.

OBRADOR PONS, Pau. 2007. "A haptic geography of the beach: naked bodies, vision and touch". Social and Cultural Geography, 8:123-141. DOI: $10.1080 / 14649360701251866$

PERIĆ, Ivo. 1983. Razvitak turizma u Dubrovniku i okolici od pojave parobrodarstva do 1941. godine. Dubrovnik: Zavod za povijesne znanosti istraživačkog centra JAZU u Dubrovniku.

POMORSKA ENCIKLOPEDIJA. 1983., br. 6, gl. urednik Vladislav Brajković. Zagreb: Jugoslavenski leksikografski zavod.

PRESTON-WHYTE, Robert. 2008. "The Beach as a Liminal Space”. U A Companion to Tourism, ur. Alan A. Lew, C. Michael Hall i Allan M. Williams. Malden: Blackwell Publishing Ltd, 349-359.

PRITCHARD, Annette i Nigel MORGAN. 2006. "Hotel Babylon? Exploring Hotels as Liminal Sites of Transition and Transgression". Tourism Management, 27/5:762772. DOI: 10.1016/j.tourman.2005.05.015

ROJEK, Chris. 1993. Ways to Escape: Modern Transformations of Leisure and Travel. London: Palgrave Macmillan.

ROGELJA, Nataša. 2004. "Izola's Fishermen between Yacht Clubs, Beaches, and State Borders: Connetions between Fishing and Tourism on the Coast". U Contesting the Foreshore. Tourism, Society, and Politics, ur. Jeremy Boissevain i Tom Selwyn. Amsterdam: Amsterdam University Press, 208-309.

RUŽIĆ, Drago. 2007. Marketing u turističkom ugostiteljstvu. Osijek: Ekonomski fakultet.

SELWYN, Tom. 1996. "Introduction”. U The Tourist Image: Myths and Myth Making in Tourism, ur. Tom Selwyn. Chichester: Wiley, 1-32.

SELWYN, Tom i Jeremy BOISSEVAIN. 2004. "Introduction". U Contesting the Foreshore. Tourism, Society, and Politics, ur. Jeremy Boissevain i Tom Selwyn. Amsterdam: Amsterdam University Press, 11-34.

SHELLER, Mimi i John URRY. 2004. "Places to Play, Places in Play". U Tourism Mobilities: Places to Play, Places in Play, ur. Mimi Scheller i John Urry. London: Routledge, 1-11.

SHIELDS, Robert. 1991. Places on the Margin: Alternative Geographies of Modernity. London: Routledge.

ŠILJEG, Klara i Ana PERINIĆ LEWIS, Joško SINDIK. 2014. "Lokalna sportska tradicija kao dio dubrovačkoga kulturnog identiteta". Zbornik Sveučilišta u Dubrovniku, 1:194-207. 
ŠUBIĆ, Nikola. 2008. Dubrovački turizam od 1857. do 2005. godine. Dubrovnik: Vlastita naklada.

URBAIN, Jean-Didier. 2002. Sur la plage: Moeurs et Coutumes balnéaires (XIXe-XXe siècles). Paris: Petite Bibliothèque Payot/Numéro: 271.

URRY, John. 2002. The Tourist Gaze. London: Sage Publication.

VEIJOLA, Soile i Eeva JOKINEN. 1994. "The Body in Tourism". Theory, Culture and Society, 11/3:125-151. DOI: 10.1177/026327694011003006

WALTON, John K. 1998. Blackpool. Edinburg: Edinburgh University Press.

WALTON, John K. 2000. The British Seaside: Holidays and Resorts in the Twentieth Century. Manchester: Manchester University Press.

WANG, Ning 1999. "Rethinking Authenticity in Tourism Experience". Annals of Tourism Research, 26/2:349-370. DOI: 10.1016/S0160-7383(98)00103-0

WEBB, Jennifer. 2003. "Beaches, Bodies and Being in the World". U Some Like It Hot: The Beach As A Cultural Dimension, ur. James Skinner, Keith Gilbert, Allan Edwards; Sports, Culture \& Society, Volume 3. Oxford: Meyer\&Meyer Sport, 77-90.

YEOMANS, Rory, 2013. "Od druga do potrošača. Odmor, slobodno vrijeme i ideologija u komunističkoj Jugoslaviji”. U Sunčana strana Jugoslavije. Povijest turizma u socijalizmu, ur. Hannes Grandits i Karin Taylor. Zagreb: Srednja Europa, 89-123.

\section{INTERNETSKI IZVORI}

http://dance.hr/ (pristup 15. 4. 2014.)

http://dubrovackidnevnik.hr/vijesti/grad/legaz-zapoceo-gradnju-vrata-na-titovoj-vilifoto-video (pristup 20. 5. 2014.)

http://www.jutarnji.hr/hrvatska-uvodi-tematske-plaze-uskoro-u-ponudi-plaze-zaljubitelje-adrenalina--partyja--nudizma-ili-pak-kulture/1289016/ (pristup 6. 2. 2015.)

KRANJČEVIĆ BATALIĆ, Tonči. 2015. "Nacionalni program pojačat će komercijalizaciju plaža i dovesti do nereda”. 4. ožujka 2015. http://pogledaj.to/drugestvari/ nacionalni-program-pojacat-ce-komercijalizaciju-plaza-i-dovesti-do-jos-vecegnereda/ (pristup 6. 3. 2015.).

Prijedlog strategije razvoja turizma $R H$ do 2020. godine. 2013. http://www.mint.hr/ UserDocsImages/130426-Strategija-turizam-2020.pdf (pristup 3. 9. 2014.). 


\section{ZAHVALA}

Zahvaljujemo dr. sc. Jošku Sindiku na kolegijalnoj pomoći pri kontaktiranju igrača Divlje lige za intervjue te Marijani Briški i Ivani Ružić za pomoć pri pronalaženju literature i informacija o povijesti dubrovačkih kupališta i vodenih sportova.

Ana Perinić Lewis

Maja Adžija

\section{THE GLOBAL AND LOCAL BEACH: DUBROVNIK TOWN BEACH AND BEACH CULTURES AS CASE STUDY}

The beach is usually considered to be a "liminal space/zone", an "anomalous category" in between land and sea, nature and culture.The dynamics of the economy, the environment, politics and social relations can be traced through it. This paper analyzes global and local beaches and their various representations, including correlations with touristic understandings, with a focus on the promotion and branding of destinations. Global beaches are presented in terms of a standardized description of places, landscapes, objects and activities relating to holidays and leisure, irrespective of coastal settlements, residents and their life and culture. The global beach stands in contrast to perceptions of the beach as a "cultural arena" (Löfgren 2002) and a "kaleidoscope of culture" (Lenček and Bosker 1998). Local, town beaches are an important symbol in the geographic landscape which local communities recognize as the area of daily and seasonal activities, cultures, lifestyles, history and specific traditions. In tourist areas there is a contradiction, with the coexistence of these two notions of beach. We analyze Dubrovnik's town beaches, as resources, spaces of fantasies, desires and expectations, and as places of belonging and of life, in which the visions, needs and traditions of local communities are met, such as the Wild League, an amateur water polo contest which takes place in the inlets and beaches of Dubrovnik.

Keywords: global beach, local, representation, beach culture, Dubrovnik, Wild league 
